\title{
The Representation of Emperor as God in Byzantine Mosaics and Frescos
}

\section{Dalila Özbay}

Namık Kemal University

dozbay@nku.edu.tr

\section{Doi:10.5901/mjss.2015.v6n4s2p58}

\begin{abstract}
The present paper focuses on the representation of Byzantine emperor as deity in the mosaics and frescos. Though there were many hesitations concerning the representation of divinity in visual images, it was considered that the figural art was able to express the sacred. Much interest was given to human body, which after the initial consideration as the locus of corruption, becomes gradually considered as the instrument reaching the divine dimension. The tangible piety gradually is regarded as a vehicle for the disclosure of the divine. As Byzantine emperor was considered to be a correspondent of divinity on earth, the artists who aim at representing a sacred dimension develop some techniques and elaborate some motifs that will reveal the emperor as holding and transmitting the transcendental.
\end{abstract}

Keywords: Byzantine mosaics and frescos, Christian figural art, Human as Divine, Divine Monarch.

\section{Introduction}

In most cultures, a work of art is appreciated by people primarily for its visual value, whereas its spiritual dimension is often disregarded. In the Byzantine art of painting, however, both the visual and spiritual dimensions are preserved. Especially the Byzantine style of mosaics and frescos can depict the invisible dimension of the spiritual. The Byzantine artists did not limit themselves to the representation of the visual aesthetics of their era, but they also tried to include into their works the philosophy and the essence of the imagination concerning their beliefs.

In a world in which stone, wood, metal and other palpable matters are visible to eye, it becomes quite difficult to represent the notion of invisible and untouchable on two-dimensional space by visual methods of perceiving. It becomes even more difficult to illustrate the spiritual dimension by using terrestrial elements.

In order to explain the terms "spiritual" and "divine" in relation to figural representation, it is first necessary to explore the origins and philosophy of the Byzantine art of painting.

\section{The Origins and Philosophy of Representation of the Byzantine Emperor as Deity}

It has always been fascinating to observe the way in which the emperor is conceived as God by the Eastern Orthodox Church and its subjects. Apparently, it might seem a paradox within the Christian religion, since it is based essentially on the doctrine of modesty and piety, and it becomes totally unexpected to see the visual representations of the mosaics and frescos on the walls of Christian churches presenting their emperor. The solemn figure and the awe-inspiring character of the emperor represented in his official patronage is impressive, but mostly remarkable is the depiction of the light of divinity which encircles the emperor's head.

However, this representation of the ruler as God does not originate in the Byzantine culture. Its roots trace back to Oriental cultures, as to mention just Egypt and Persia. The Egyptian pharaoh Amenhotep IV, the first ruler who proclaimed monotheism, viewed himself as a god, and the visual representations on the clay tablets as well as on the walls of the temple represent the figure of the pharaoh encompassed by the golden rays of the sun.

In Persia this idea of the divine monarch developed and continued. In the times preceding the prophet Zoroaster, the Persian ruler possessed hvarena, which was considered to be a kind of awe-inspiring glory received from the God of Light. In the visual representations this ruler is surrounded by a luminous halo of kingly glory. The radiant diadem around the king's head and the glimmering robes worn by the king emphasized the divine origin of the ruler.

The Persians believed that the microcosm signifies the man and is represented similarly to the four estates of the world, so that the head coincides with the estate of priests, the hands coincide with the estate of warriors, the belly corresponds to the estate of cultivators, and respectively the feet correspond to the estate of artisans. According to this 
belief, God - the creator of mankind - has enforced a social order in which the head should rule all the limbs. The most fervently applied religious cult of the Persians, Zoroastrianism, is based on the dualism of good and evil god. The prophet Zoroaster taught his disciples "to uphold the cause of the god of light with ritual and moral behaviour, a head laid a messianic deliverance, the resurrection of the dead and life everlasting after judgment" (Krassel, 2009, p. 297). The kings of the Orient, thinking that the divinely wisdom was given to head, implemented the extreme dualism of Zoroastrian cosmology into the social and political order.

Since many of the notions of Persian and Egyptian culture were inherited by the Greek philosophy, it would not come as a surprise to discover that Aristotle considered that the ideal image of the king should be the earthly equal of Zeus. Following the Persian model, the Hellenistic monarchs assumed this perception of a divine king. In a surprising anthology of essays on kingship, dating back to the $6^{\text {th }}$ century A.D., its author John Stobaeus gathered the ideas of some ancient philosophers belonging to a much earlier period. In this book we see that "'Archytas' declares that the king is animate law. 'Sthenidas' declares that the wise king is the imitation and the representative of God. 'Diotogenes' declares that as God is in the universe so the king is the state, and he adds that the state is an imitation of the order and the harmony into a god among men. Still mere significantly, 'Ecphatos' say that the logos of God, which sows the seeds of order and visits man to restore what has been lost by sin, is incarnate in the king. * Some time later Plutarch takes this up. He says that God has set up as His image in Heaven the sun and the moon, and in earthly polities a similar copy and radiance, the king, who should have as his guiding principle the logos" (Runciman, 1977, p. 21).

The same idea was adopted in the Roman Empire, mostly through cultural and political relations with the Oriental civilization. Due to these relations, there emerged completely new theories and perceptions of life, which led to the creation of new concepts, the most important ones being the concept of a conqueror-emperor and that of a divine monarch. Although the Roman emperors became Christian, they did not hesitate to impose on their subjects the idea that their emperor was a god. They have changed the ritual and the visual techniques of the preceding cultures to fit their new religion. Nevertheless, this ritual was used to represent primarily the emperor's sacred nature. The Christian cosmology's own dualistic tendencies proved extremely efficient when the emperor presented his deeds as divinely ordained, whereas the adversaries as demoniac.

The Byzantine culture represents the synthesis of all these earlier influences, but it will take its own course of development especially after the conversion of the emperor Constantine to Christianity and the transfer of the capital from Rome to the ancient city of Byzantium at the end of the Bosphorus, which was later renamed as Constantinopole (modern Istanbul). From now on the name of this city started to be associated with the art and civilization that has grown and refined under Christian and imperial patronage.

The Byzantine Empire, as a political continuation of the Roman Empire, preserved the governmental system within a theocratic Christian state. This historical, political and religious peculiarity gave rise to a new, unique art which was no longer Roman.

\section{The Debates Around the Representation of the Divinity in the Byzantine Art}

The Byzantine art is especially noteworthy for the mosaics and frescos which decorate the interiors of the churches. Most of the Byzantine churches had a special program of decoration. The mosaics were regularly formed on uneven surfaces, so that there would be an opportunity provided for the little pieces of shimmering gold or glass to be caught by the sunshine or the light of the candles, by which creating an almost celestial brilliance. The depiction of Christ as a judge giving his blessing with his right hand raised or pointing to the Gospel book is likewise impressive. The purple robes of Jesus, which signify his divine status, Christ holding a jewelled crown to Saint Vitale, as well as the lavish use of gold in the background give the impression of opulence and sumptuosity. This unexpected custom of adorning the interior walls of the churches aimed at overawing the spectator "by means of an inconceivable splendour which would, when combined with the impression produced by the chanting, the vestments, and the wealth of the relics, leave him spellbound and astounded" (Talbot, 1962, p. 79).

For the Byzantines, the religious services preserved something from the ancient Greek theatrical performance, namely its blend of beauty and ceremony. Therefore, the display of the rarest beauty in the church on such a grandiose scale by the Byzantine artists had both an artistic and a sacred function. In the Byzantine churches,

all the arts were made to collaborate: the monumental architecture, the mosaics and paintings on the walls and vaults, the pictures, the liturgical ornaments and vestments, the ritual and the chants, the words and the melodies - all were designed to give aesthetic delight, and thus raise the soul to God. Byzantine ritual was characterized by what has been called 'mystical materialism'. Material splendour was used to put across mystical ideas and to lead to God through aesthetic experiences. (Tatarkiewicz, 2005. p. 36) 
This display of splendour produced both by the sacred ritual and the artists in the Byzantine churches was interrupted by a fierce religious dispute, known as Iconoclastic Controversy. It was insisted upon the fact that the Bible prohibits the representation of sacred images and that, in creating images, the artists make use of the creative act which belongs to God alone.

This hostility towards art was caused mostly by fear of idolatry than by the figural art per se. Since Christianity developed from within a cultural background in which temples and images were a commonplace, the Christian apologists were much eager to condemn the idolatry. It was considered that the figural art represented the "soulless" and the "dead", whereas the Cristian ritual of worship was admirable especially because it was spiritual (Finney, 1994, pp. 15-39).

In the Christian environment, the protest was directed against the pagans who worshiped images of their gods and philosophers. The conflict increased with the dilemma centred on the human capacity of representing a spiritual reality and also on the possibility of a dead matter to represent a living reality. The impasse pointed to the lack of necessity of worshiping any images of gods and that the people willing to worship could look to heaven for it. In this respect, Arnobius of Sicca (fl. Late third century), questioned whether gods would fail to see that they were being worshipped by people without being represented on images. He insisted that none of the images produced by the artisans from earthly, thus vile matter, would prove the capacity to represent the unearthly and the sacred. Therefore, Arnobius of Sicca asked whether there is any meaning in making these images (Arnobius of Sicca, 1949, pp 460-67).

Hostile commentators raised multiple questions concerning the representation of the sacred in the visual art. The most persistent theme of these comments consisted of the superiority of spirit over matter. Primarily, it was considered that the material things, partially due to their matter and partially due to the fallibility of the craftsmen who make them, do not represent suitable channels for expressing the sacred or a ritual of worship. Second, the pictures made by the artisans were pointed to be indeterminate, since how was one supposed to make a corporeal image to an incorporeal being. Moreover, in the context of this vague representation, the problem extended to the meaning which is produced by the image and which would have an impact on devotion.

Although the circumstances for the emergence of the Christian figural art were unfavourable, the fascination with the visual representation, already as early as the fourth and the fifth centuries, turned into a genuine flourishing of art in various forms, such as sculpture, fresco, painting, mosaic, glass, and even metalwork. Gradually, in some private spaces, various abstract symbolic representations of biblical scenes appeared. The Cristian artists strove to represent more and more subjects from Scripture and even the figure of Christ Himself. After the proclamation of Christianity as a legal religion, many patrons, accustomed to richly decorated spaces, were tempted to offer space and opportunity for artistic talent, so that their elegant mansions became ornamented with paintings, mosaics and glass. Later, the rich mosaics, frescos and paintings moved to decorate the interiors of the Christian church.

Various explanations have been provided for the created situation. Some scholars pointed to the combination of the popular superstitions with the persistence of pagan rituals in an unholy compromise between the sacred and the profane, or that the Christians adjusted some of the motifs and themes of the imperial art to their own use (Ladner, 1953, pp. 1-34). A current view is based on the assumption that Christians grasped the art as a medium for "providing spiritual readings of the Old Testament and, hence, for rendering spiritual exegesis accessible. (...) Pictures could render the Jewish story intact and, at the same time, reveal its hidden significance" (Kessler, 1992, p. 54). In other words, Christians tried to deliver the words of the Old Testament in pictures and images of their own making. This Christian art emerged and proliferated rapidly, although it also appropriated much from the pagan tradition in terms of style, theme, motif, and technique of production.

In this background of hostility towards the Cristian art, there was also a powerful tendency to defend this newly emerging art. By the fourth and fifth centuries, the Christian figural art developed extensively. The sacred image cultivated its own conception of divine presence. Among those who encouraged this form of art is St John of Damascus who explains that "when we venerate images, it is not veneration offered to matter, but to those portrayed through matter in the images. Any honour given to an icon is transferred to its prototype" (John of Damascus, 1980, p. 89). The aim of image is to serve as a pathway which leads to the prototype. In a way, the prototype is accessible when it is present in an image. Moreover, as St Simeon puts it, "When we see the invisible through the visible picture we honour Him as if He were present" (Kitzinger, 1976, p. 153). In the same line, Pseudo-Denis explains that "we are led up, as far as possible, through visible images to the contemplation of the divine" (Pseudo-Dionysius, 1987, 145). In a way, for many people, the image grew into a point where anagogy met theophany. As heavenly grace and blessing was transmitted downward, similarly the spiritual energy of the viewer was expected to be channelled upward. An image, therefore, became capable to represent and even to mediate the contemplated thing to the observer. Certainly, the Neoplatonic thought contributed greatly to the collapse of the barrier which detached the image from the represented thing. 


\section{Defining Divine Presence in the Byzantine Art}

The concept of dualism of existence between the antagonistic forces of good and evil, inherited from the philosophy of the Orient, accommodates itself in the Cristian religion, developing into the dualism of matter and spirit. The dualist vision of human creates the antagonism between body and soul, represented as a fight between the matter and the spirit. In the Christian culture this antagonism has been resolved by the triumph of the spirit over the matter. The hostility towards the matter - seen as the locus of the evil - led to a diminution of value of the material forms and to a loss of interest in their development, a fact which had a great impact on the course of medieval art.

Nevertheless, the great fascination that the ancient Greek artists had had for the human body managed to pervade into the Byzantine culture, although in a considerably modified artistic representation. In the Christian culture, the human body is not appreciated for its evocation of beauty, which signified the completion of the idea of harmony in the matter. Instead, the human body was represented in the Byzantine art for its quality of evoking a new reality which is the spiritual dimension and which transcends the matter. Around the fourth century, the religious significance of the material world gradually became re-evaluated, so that the material world, especially the human body, was considered as an instrument of reaching the transcendental. The shift occurred from "sensory austerity" to a tangible, "palpable piety", as the sensible world started to be regarded as a vehicle for the disclosure of the divine (Harvey, 2006, p. 46, 58). As Harvey suggests, the human body "gained worth for Christians as a means for knowing God" (Harvey, 2006, p. 46).

This movement from the concept of human body as the locus of evil to the concept of human body and its sensorium as the locus for religious epistemology was slow and met many obstacles. On one hand, there was a positive attitude which insisted on the fact that body could function as "self" in the process of transfiguring the being towards its true status as image of God. On the other hand, the negative attitude revealed the impossibility of transfiguring the human being in the present, due to the embodiment per se, which is subject to decay, special limitation, and moral imperfection. In other words, corporeality was poised on the boundary line between the visible and invisible, intelligible and sensible.

The Neoplatonists, and especially Plotinus, contributed to the establishment of the new aesthetics which is based mostly on the idea of spiritual perception. Plotinus insisted that the divine could not be materialised in two-dimensional representations. Corporeal presence is opposite to the idea of incorporeality of the divine nature. Therefore, to him, the visual representation of the divine nature could be transposed in a picture by transferring its significance into an iconographic symbol.

The concept of image as a prototype representation entered into Byzantine theology and then art through Plotinus and the Christian Neoplatonists, and became a fundamental aspect of the Eastern Orthodox worldview. The essential part of this philosophical tradition correlates the definition of the symbol with the idea of non-conceptual information, carried by the image. St Dionysus the Areopagite, the one who promoted this idea in the Christian world, speaking of ontological hierarchy and the transfer of knowledge, claims that "those beings and those orders which are superior to us (...) are incorporeal and (...) their hierarchy belongs to the domain of the conceptual and is something out of this world" (Pseudo-Dionysus, 1987, p. 197). But the human hierarchy is suffused by a diversity of visible symbols which conduct us hierarchically, according to our capacity of unified deification, to "the oneness and deifying simplicity of the Father" (Pseudo-Dionysus, 1987, p. 145). Pertinently, superior beings comprehend as pure intellects, whereas the humans are conducted, as far as possible, to the contemplation of the divine only "by way of perceptible images" (Pseudo-Dionysus, 1987, p. 145). In this manner, it is suggested that the symbol cannot be grasped by human reason; however, the divine truth is incorporated in the symbolic form. As a consequence of the above mentioned aspects, the assertion that the image is a symbol confirms that the image is the most competent form in which the truth is revealed to man.

Given that a visual representation may contain divine presence, the Byzantine artists used paining as a means of reaching the divine. The artist was not preoccupied by the representation of certain aspects of human form, but mostly on its essence. The essence was identified with the idea, or eternal prototype. In the Byzantine art of painting, the temporal forms suggest a correspondence to the prototype. The purpose of the Byzantine theological art was to fix the mind of the beholder on the prototype, to direct his attention to the eternal and, consequently, to raise his mind to the contemplation of God. It was considered that art was only a means, not an end; its real purpose was to establish a contact with the divine, which was available through the contemplation.

\section{The Representation of Human as Divine in the Byzantine Art}

In its long history, the Byzantine art remained faithful to a number of stylistic principles which provided its unity and originality. The representation of the human being was a constant preoccupation in the Byzantine art, although its relation 
to reality and the perception of the beholder endured profound modifications. In a way this art gave an artistic expression to the correspondence of the image between man and God, since, as Eugene Kleinbauer claims, without ever quite giving up the natural substratum of the human body, it manages negatively by dematerialization and positively by mood and manner to express through bodily form the presence of the immaterial soul, and the whole realm of the spirit to which it belongs. (Kleinbauer, 2001, p. 437)

The Byzantine type of the holy man corresponds to the image of the human being which is purified of matter and placed at a great distance from the ordinary man. This aspect becomes visually suggested by the isolation of the holy man into a supraterrestial space, indicated by the high line of the horizon and the nature which, by its irreal depiction, is full of grandeur. This image of the holy being, in his harmonization with nature and with human being, predominates in the Byzantine mosaics and paintings of Ravenna and Istanbul.

Another aspect in the depiction of the body image in the Byzantine art is connected with its resemblance of and difference from reality. The resemblance of the image and reality, most frequently imagined, had the purpose to confer the value of prototype to the upcoming representations so that the image had to be recognizable. The difference from reality was necessary to convey the symbolic value of the image; the abstract representation could evoke better the elevation of the spirit to divinity.

This ideological principle was transformed by the Byzantine artists into a stylistic principle, which ensured a harmonious relationship between the abstract and reality. The artists of the Byzantine mosaics and paintings, in their tendency toward abstraction, tried to dematerialise the body by flattening it, by covering it with elaborate drapery. In the representation of the figure and the physiognomy, the shimmering diagrams suggest the radiance of the divine energy in a God governed universe. The sacred dimension is also suggested by the grandiose corporeal proportions, the static physiognomy and the splendour of the bright mosaic's glitter.

The religious character of the Byzantine art of mosaic and painting did not prevent the manifestation of the artistic imagination and personality of the artist. The historical development of the Byzantine culture and empire led the artists of the period to shape their imagination in the outstanding mosaics and paintings representing the emperor in the hypostasis of God. In the centre of the mosaics representation stand the emperor and the empress in the splendour and luxury of the imperial court, but in parallel to this, the widely open eyes, and the severity and the gravity of their features place these immobile characters into a transcendental world.

\section{The Development of the Byzantine Art of Paining in Its Theological Context}

Whenever the evolution of the Byzantine art of painting is analysed in its theological context, this Byzantine art is generally defined as an art of Christianity. When the Orthodox Christian religion expanded to territories such as Antioch, Alexandria, Syria and Palestine, it created a great impact upon the nature and causes of the development of this Christian art. The Orthodox tradition and dogmatic causality marked the change of aesthetic perspectives and they also contributed to the flourishing of the Byzantine art.

The religious expression that characterized Byzantine art developed within a rigid tradition, connected to the cult of emperor. In this respect, Steven Runciman mentions the following:

The constitution of the Byzantine Empire was based on the conviction that it was the earthly copy of the Kingdom of Heaven. Just as God ruled in Heaven, so the Emperor, made in His image, should rule on earth and carry out His commandments. (Runciman, 1977, p. 202)

The Byzantine emperor embodied something tangibly to the divine on earth. The Roman emperor, as well as everything associated with domus divina, was believed to be sacred. The spreading of Christianity in the Roman Empire did not alter much the emperor's sacred aura. The Byzantine Christian emperors insisted also on their divine quality, and anything "utilized within their sacred aura became sacer, sacratissimus, or divinus. Their orders were composed on altaria and referred to as caeleste oraculum, any disregard of which was sacrilegium" (Canepa, 2010, p. 100).

The position of the Byzantine emperor as a correspondent of divinity did not derive only from the cultures of the Orient. It may have its origin also in the autocratic form of the Byzantine government. In this autocratic system of government, the supreme power was concentrated solely in the hands of the emperor and his decisions were never contested during his life.

In this context, the products of the Byzantine art of painting would be developed within a powerful autocratic system of government. The emperor and the Christian Church became active patrons of the Byzantine art, and, at the same time, the constant objects of Byzantine artistic representation. The art which portrays the emperor's sacredness, 
together with the depicted ritual performed around the imperial figure, served as a complex and subtle message about the identity of the emperor.

The artists of the period, highly fascinated with the status of the emperor, tried to depict their ruler not only in the light of divinity, but also in a triumphant and sumptuous space. Apparently these visual representations aimed at the illustration of the king's authority, but they led inevitably to the growth of the concept of the monarch as a divine power.

Dominated by the strong authority of the Byzantine emperor and, concomitantly, captivated by the possibility of a complete sovereignty of a man, the Byzantine artists developed an unusual but uniform and impersonal kind of art that did not change for centuries. This newly established art had also another characteristic, namely

it was an imperial art. The reason for this resides in the very nature of the Byzantine monarchy; the emperor was an Eastern sovereign, an incarnation of Divinity, and His representative on earth. Art was placed at the service of the prince to glorify him. (Pall Mall Encyclopaedia of Art, 1971, vol. I, p. 301)

The emperor made use of visual art of painting, mosaics and frescos in order to impose his royalty. Such markers as diadem, nimbus, and red shoes became predominant visual motifs used by the Byzantine artists to symbolize the sovereign's luminous royal power. It was Constantine who introduced the diadem as a compulsory attribute of royalty. He also felt extreme delight in adorning his clothes with pearls and precious stones. The pomposity and the wealth of the emperor's costume functioned as a visible symbol of his power. In the same manner, Justinian and Theodora would always appear in the prominence of red leather, silk and pearls, an image which suggested the imperial superior position. Since the Byzantine emperors were in a continuous competition with kings of the Orient, an enormous effort was put into cultivating their superior image of royal identity, both in person and as artistic representation.

This attitude of the Byzantine emperors towards their own personalities determined the penetration of these displayed images into the artistic realm. The ornamental motifs, such as the nimbus, diadem and textiles worn by the members of imperial families and inscribed in the mosaics and frescos on the walls of the churches, are impressive. The Byzantine artists carefully inserted these motifs of dominance and authority in the official representations of their emperors. In these visual representations, the Byzantine artists portrayed their emperors as outstanding leaders holding control in the world. In other words, the use and display of visual imagery representing royal power functioned as a strong political symbol. The Byzantine artists, being materially sponsored almost exclusively by aristocrats or royalty, made their art, in a way, subservient to the aristocratic ideology of the imperial court.

The Emperor learned quickly to explore and exploit completely his position within the empire and the Church, so that

"by the end of the fourth century the Emperor was the holy Emperor, living in the Sacred Palace surrounded by liturgical ceremony, and, so long as he were worthy, revered as Viceroy of God; and the Emperor in his turn was devoting energy and riches to the glory and welfare of the Christian Church" (Runciman, 1971, p. 17)

Although religious in its essence, and true and noble in its expression, the Byzantine art of painting was submissive to the grandiose interests of the imperial court.

\section{The Representation of the Emperor as a Divine Monarch in the Byzantine Art of Mosaic and Fresco}

In the art of paining of the Byzantine period the power of the emperor was interpreted as the power of divinity. It was of essential importance to reflect in the art of mosaics and frescos that the emperor ruled in the world under a divine mandate. Starting with the third century A.D. and continuing through the fifth-and sixth centuries the imperial art emphasized the parallels between the empire and the world, the emperor and the Christian God, and especially the emperor as a God's endowment for the world's well-being.

In this respect, references to royal attributes and objects of clothing, which are represented on mosaics and frescos, present a certain critical interest.

First and most relevant is the nimbus. There is a scarce account concerning the history of artistic representation of this royal marker in the Mediterranean, Near East, and Central Asia. Most probably a part of Oriental cultural inheritance, the nimbus became an attribute of the Roman sovereign around the last decades of the third century. The emperor Constantine, who truly believed that the Christian emperors were doing divine work in saving the world from satanic creatures, established the nimbus as an essential element of the representation of the Roman ruler. The disk of light which surrounds the divine head, the nimbus, became gradually a predominant motif in the Cristian art and even entered the imperial iconography. This motif was soon taken over and used by the imperial art, such as Constantine II's and 
Theodosius' silver vessels, but its most impressive artistic representation is reified by Justinian's mosaics of San Vitale from Ravenna and Constantine's mosaics of Hagia Sophia from Istanbul.

In the Byzantine world, Constantine and Justinian were considered as paradigms of kingly wisdom working for the salvation of the soul and empire. Therefore, in mosaics, which served as a visual statement of religious and political expression, this idea is strengthened not only by such royal markers as nimbus but also by the diadem.

The diadem, in the pagan world, was an important symbol of monarchical power and victory. It was introduced into the Christian world by Constantine as a part of the visual and political experimentation with the imperial image. Constantine explored various versions of diadem, adding pearl, gem appliques and many other ornaments, among which the most important one being the cross. The artists of the period were careful in representing the imperial crown as a symbol of sovereign's statements of global power and legitimacy.

Apart from the headgear, there were other more subtle elements of royal dress. Bejewelled footwear and the expensively dyed silk robes, popular among Roman emperors, were adopted by the Byzantine imperial costume. In the mosaics of San Vitale from Ravenna, Justinian is depicted in the prominence of red leather and pearls, whereas Theodora's purple cloak, which is created from an extremely expensive dye, provides a metonymical link between the person and the office of the emperor.

The art of mosaics and frescos depicts various sacred rituals. The emperor, who is the image of divinity, becomes par excellence an essential part of these rituals. A very famous example, found on the walls of Hagia Sophia, is the mosaic representing Virgin and the Child who receive the gift of the city from Constantine and the church Hagia Sophia from Justinian. The emperors' philanthropic works interspersed with the miracle of Christ's birth. The artist skilfully elaborates a daring functional equivalency between the works of Christ and the ones of the emperors in this mosaic.

Another example, found again in the mosaics of Hagia Sophia, represents the Savoir enthroned between Constantine IX and Empress Zoe. Constantine donates a bag of gold and Zoe a scroll recording donations to the church. The physical connection between the images implies a parallel between Christ's offerings to humankind and the emperor's gifts to the church.

In the same manner, the small but impressive detail of the three Magi on the hem of Empress Theodora's chlamys, depicted in the mosaics of San Vitale, reveals the significance of the empress's ritual activity. Theodora's offerings on the altar create a semantic equivalence to the gifts of the three Magi offered to the true Sovereign (Tetneriatnikov, 1998, pp. 381-91).

As any visual image, the above mentioned mosaics, which include the motifs of royal markers and the ritual, are endlessly polysemantic. In order to be effective and transmit the necessary message, this polysemy had to be shaped and controlled. Therefore, the Byzantine artists who were under the patronage of the imperial court, had to shape the message of their mosaics and frescos into a coherent narrative, which would imply that the Christ's earthly representative is the Christian emperor. The emperor is the only one who practices the legitimate authority at least within his own culture.

\section{Conclusion}

Although extremely controversial, the Byzantine figural art emerged and spread rapidly and widely in the Christian world. Sometimes this art would be influenced by the theological debates such as "anthropomorphism". On the whole, the Byzantine art promoted and expanded various issues and stimulated various arguments, as the following: art was suitable for the instruction of the ignorant; art arouse emotions in ways that words at times failed to do; art reminded people of sacred heroes; art conveyed in people deeper thoughts about higher things; and art was made of perishable matter, but this was only circumstantial to the aim of art. Images evoked miracles, and, as the visual effect was more powerful that the auditory one, it was more efficient to spread the meaning of miracles through visual representations. The Byzantine art was definitively an imperial art which promoted the image of the emperor as a divine ruler. This image of the Byzantine emperor in the divine representation was used to impose the superiority of the emperor in the world, and the image representing the emperor strengthened the honour given to the emperor.

\section{References}

De Krassel, P. G. (2009). Custom Maid Knowledge for New World Disorder. Casemate Publishers.

Runciman, S. (1977). The Byzantine Theocracy: The Weil Lectures. Cincinatti Cambridge University Press. Runciman, S. (1971). Byzantine Style and Civilization. Penguin Books. England.

Rice, D. T. (1962). Byzantine Art. London: Pelican Books. 
Pall Mall Encyclopaedia of Art. (1971), London. Cromwell Place. Vol. I

Tatarkiewicz, W. (2005). History of Aesthetics. Vol. 2, London: Polish Scientific Publishers, London. Edited by J. Harrett and D. Petsch. Finney, C. (1994). The Invisible God. Oxford: Oxford University Press.

Arnobius of Sicca. (1949). The Case Against the Pagans, 6.9, 10, 12-13,14, 16. Trans. McCracken, G. E. Newman Press.

Ladner, G. B. (1953). The Concept of the Image in the Greek Fathers and the Byzantine Iconoclastic Controversy. In Dumbarton Oaks Papers 7.

Kessler, H. L. (1992) 'Pictures Fertile with Truth'. The Journal of the Walters Art Gallery Vol. 49/50.

John of Damascus. (1980). On the Divine Images. New York. Crestwood.

Kitzinger, E. (1976). The Art of Byzantium and the Medieval West. Indiana University Press.

Harvey, S. A.(2006). Scenting Salvation: Ancient Christianity and the Olfactory Imagination. The Transformation of the Classical Heritage 42. Berkeley: University of California Press.

Pseudo-Dionysus. (1987) 'Ecclesiastical Hierarchy' in his The Complete Works. Trans. C. Luibheid and P. Rorem. London: Society for the Promotion of Christian Knowledge.

Pseudo-Dionysus. (1987). 'Celestial Hierarchy' in his The Complete Works. Trans. C. Luibheid and P. Rorem, London: Society for the Promotion of Christian Knowledge.

Kleinbauer, W. E. (2001). Modern Perspectives in Western Art History: An Anthology of Twentieth Century Writings on the Visual Art. University of Toronto Press.

Canepa, M. P. (2010). Two eye of the Earth: Art and Ritual of Kingship between Rome and Sasanian Iran. CA, USA: University of California Press.

Tetneriatnikov, N. (1998) "The 'Gift-Giving' Image: The Case of Adoration of the Magi," Visual Resources 13. Routledge. 